Interorganization Role-Set Relations and the Performance and Satisfaction of Industrial Salesmen

Author(s): Henry O. Pruden and Richard M. Reese

Source: Administrative Science Quarterly, Vol. 17, No. 4 (Dec., 1972), pp. 601-609

Published by: Sage Publications, Inc. on behalf of the Johnson Graduate School of Management, Cornell University

Stable URL: http://www.jstor.org/stable/2393837

Accessed: 27-02-2015 18:39 UTC

Your use of the JSTOR archive indicates your acceptance of the Terms \& Conditions of Use, available at http://www.jstor.org/page/info/about/policies/terms.jsp

JSTOR is a not-for-profit service that helps scholars, researchers, and students discover, use, and build upon a wide range of content in a trusted digital archive. We use information technology and tools to increase productivity and facilitate new forms of scholarship. For more information about JSTOR, please contact support@jstor.org.

Sage Publications, Inc. and Johnson Graduate School of Management, Cornell University are collaborating with JSTOR to digitize, preserve and extend access to Administrative Science Quarterly. 


\title{
Interorganization Role-Set Relations and the Performance and Satisfaction of Industrial Salesmen
}

\begin{abstract}
In this study*, the outside salesman was viewed as engaging in power, authority, and status interactions to coordinate an exchange relationship and these relationships were seen as determining his performance and satisfaction. Linear discriminant functions were developed, one for performance and one for satisfaction. Findings from a survey of ninety-one outside salesmen showed that high and low performance and satisfaction were significantly different from each other along dimensions of power, authority, and status, as determined by the discriminant function. Two distinct discriminant functions for performance and satisfaction emerged.
\end{abstract}

This is an exploratory study of the outside salesmen of a large forest products company. As a boundary person, such a salesman has a role set extending outward into his customer's organization and inward into his employer's organization (Miller \& Rice, 1967; Evan, 1965), and his task is to reconcile the partially conflicting goals and expectations of supplying and purchasing organizations in an exchange relationship (Litwak \& Hylton, 1962; McGary, 1951; Pruden, 1969a).

This report focuses upon identifying the specific interorganizational power, authority, and status relations that distinguish between high and low performance and high and low satisfaction; therefore a linear discriminatory analysis was performed on each of these two dependent variables to derive criteria for classifying salesmen on the two variables.

\section{ROLE-SET RELATIONS}

\section{Power, Authority, Status}

Power, authority, and status are the main ways of interaction among persons within and between organizations, and they are the key elements in Dubin's (1958 and 1968) theory of organization.

Power refers to the relations among organization members according to the degree

\footnotetext{
* The authors wish to thank Robert Pethia for his suggestions and criticisms of various drafts on this article.
}

of exclusive control that a member has over the performance of functions essential to the development and maintenance of the organization. Since the control over essential functions by a salesman provides him with a power basis for influencing the behavior of other organizational members, it was assumed that the power of the salesman increased as his discretion over alternative choices with respect to functions increased. Salesmen may expand their power by increasing their discretion over functions essential to consummating transactions. In this study, these functions were identified as the independent variables of credit, delivery, price, and product functions, which are activities of a transaction channel (Fisk, 1967). Power may also be increased through more exclusive access to customer accounts.

Authority relations refer to those in which an organization member makes and transmits decisions to another member, expecting that they will be accepted; and the recipient expects such decisions and acts in accordance with them. The authority of salesmen was measured by the suggestions which salesmen made to members of their role set. It was assumed that a salesman interacted with his role set on a predominantly horizontal authority level. Landsberger (1961) argued that the concept of authority should be applied to horizontal relationships and, in a study of horizontal work flow, he focused upon the 
origin and reception of suggestions as a measure of horizontal authority.

Salesmen may widen the range and domain of their authority (Cartwright, 1965); by increasing the number of agents over whom they exercise influence and by exerting direct rather than indirect influence. It was expected that the authority of a salesman having nonformal authority relations with a large number of agents would exceed the authority of a salesman who sought to influence a formal authority holder, who, in turn, influenced a wider range of agents. In this study, the agents over whom a salesman attempted to establish authority were the warehousemen and inside salesmen within his company, and the yardmen, credit men, and sales clerks in the customer's organization.

Status relations refer to people's perception of each other's position; that is, whether they perceive each other as equals or as superiorinferior. Previous studies support the hypothesis that status equality between sellers and purchasers increases the likelihood of a sale (Ditz, 1967; Evans, 1963; Gadel, 1964; Wittreich, 1962). Status equality between salesmen and their customers increases as the perceived similarity and familiarity between salesmen and their customers increases (Evans, 1963). Salesmen were asked to indicate the degree to which customers were like or unlike themselves, and the extent to which they were familiar or unfamiliar with their customers' personal and business goals. With respect to outside salesmen status equality refers, therefore, to the relation between a salesman and owner-managers or purchasing executives of the customer organizations.

\section{Performance and Satisfaction}

The job performance and job satisfaction of salesmen indicates the degree to which organizational and personal goals are reached. Performance was measured by a self-rating scale adapted from the one designed by Pym and Auld (1965) for use in ambiguous situations. A pretest conducted in several of the organization's west coast offices indicated that an annual review of the salesmen was the basis of their self-rating. Because of the congruence with supervisory ratings and selfrating and the unavailability of a review of salesmen by their supervisors on a national scale, the questionnaires containing the pretested self-rating scale were mailed to the salesmen immediately following an annual review. The self-rating scale was also preferred because of disagreement as to what constitutes a valid measure of personal selling performance and the difficulty of isolating each salesman's performance in the light of his interdependence with other organizational members. Satisfaction was measured by a self-rating index developed by Tausky (1963) and Tausky and Dubin (1965).

Since several previous studies had indicated that there was little or no correlation between performance and satisfaction (Cotham, 1968; Katzell, et al., 1961; March \& Simon, 1959), two separate discriminant functions were developed, one comprising the independent variables and high and low performance measures; the other with the same independent variables and measures of high and low satisfaction. A pretest gave a correlation coefficient of 0.03 between performance and satisfaction.

\section{RESEARCH DESIGN}

This study was designed to determine whether the relations of power, authority, and status among a group of outside salesmen could discriminate high and low selling effectiveness in terms of performance and satisfaction.

A random sample of 126 outside salesmen employed by a national producer and distributor of wood products responded to a selfadministered mail questionnaire. All respondents were male, had at least nine months' sales experience with the company, and their ages ranged from early twenties to late fifties with a median age of thirty-six. They were selling a broad line of building materials to retail, contractor, and industrial users throughout the nation. Ninety-one salesmen returned usable questionnaires, a response rate of 72 percent.

The questionnaire contained seventy-five items, seventeen of which were used in this study ( see appendix), twelve relating to the three independent variables, one to the performance variable, and four to the satisfaction variable. Each of the five independent variables relating to power (credit, delivery, price, types of products offered, and exclu- 
sivity of customers) and satisfaction were measured by a six-point Likert-type scale. The authority variables (warehousemen, inside salesmen, yardmen, sales clerks, and collections), the status variables (similarity and familiarity), and the performance variables were measured on either a four- or fivepoint scale. Performance and satisfaction were dichotomized into high and low groups.

Since the purpose was to classify salesmen, as well as to determine the relative importance of the independent variables, a discriminate function, a linear combination of the independent variables, was developed to classify observations, that is, salesmen, into categories. Although this aggregate function is important, equally important are the coefficients that form the linear combination of independent variables. The computational procedures used to find the discriminant function followed Green and Tull (1966: 351). "Select coefficients for the discriminant function in such a way as to maximize the probability that an element assigned to a particular group is, indeed, a member of that population."

\section{FINDINGS}

In the present study a linear discriminant function, $\mathrm{Y}^{*}=\mathrm{c}_{1} \mathrm{x}_{1}+\mathrm{c}_{2} \mathrm{x}_{2} \ldots+\mathrm{c}_{\mathrm{n}} \mathrm{x}_{\mathrm{n}}$, was chi-square, can be used as a test of significant difference. Given a $\chi^{2}$ value of 16.234 for performance, and given that the proposition implied direction, the hypothesis of equal means between high and low groups can be rejected at approximately the 0.08 level (Blalock, 1960: 218). Likewise, satisfaction with a computed $\chi^{2}$ value of 17.720 , shows a significant difference between the high groups at the 0.07 level (Blalock, 1960: 218).

How well do these independent variables discriminate between the two groups? The classification matrices for the two linear functions are as follows:

\begin{tabular}{lccccc}
\hline & $\begin{array}{c}\text { Performance } \\
\text { Classified }\end{array}$ & & \multicolumn{2}{c}{$\begin{array}{c}\text { Satisfaction } \\
\text { Classified }\end{array}$} \\
\cline { 5 - 6 } Actual & High & Low & & High & Low \\
High & $40^{*}$ & 19 & & $36^{*}$ & 15 \\
Low & 11 & $21^{*}$ & & $14^{*}$ & $26^{*}$ \\
\hline
\end{tabular}

* Number correctly classified.

The discriminants correctly classified 67 percent $(61 / 91)$ for performance and 72 percent (66/91) for satisfaction. A comparison of the number correctly and incorrectly classified with those expected by chance using chisquare analysis gives the following:

\begin{tabular}{|c|c|c|c|c|c|}
\hline \multirow[b]{3}{*}{ Expected } & \multicolumn{2}{|c|}{ Performance } & \multirow[b]{3}{*}{ Expected } & \multicolumn{2}{|c|}{ Satisfaction } \\
\hline & Correct & Incorrect & & Correct & Incorrect \\
\hline & 49 & 42 & & 46 & 45 \\
\hline Classified & 61 & 30 & Classified & 62 & 29 \\
\hline$\left(C_{1}-E\right)^{2}$ & 2.94 & 3.43 & $\left(C_{1}-E\right)^{2}$ & 5.57 & 5.69 \\
\hline
\end{tabular}

derived for each of the criterion variables, performance and satisfaction, based on the response to the salesmen's rating of twelve independent variables. The answers to two questions (Morrison, 1969) were sought: (1) how well do these independent variables discriminate for satisfaction and performance? and (2) which of the independent variables are good discriminators?

Before these questions could be answered, a test of significance was necessary to demonstrate that these two groups were, in fact, from different populations. The generalized mahalonobis D-square value, converted to
The expected frequencies were calculated by multiplying the proportional criterion $\mathrm{C}_{\mathrm{pro}}$ and one minus the proportional criterion by the total sample size. The formula for the proportional criterion is $\left(\mathrm{C}_{\mathrm{pro}}\right)$.

$$
\mathrm{C}_{\mathrm{pro}}=\mathrm{P}^{2}+\left(1-\mathrm{P}^{2}\right)
$$

where:

$\mathrm{P}=$ proportion of individuals in high groups

$1-\mathrm{P}=$ proportion of individuals in low groups

For example, for performance,

$$
\begin{aligned}
& \mathrm{P}=59 / 91=0.65 \\
& 1-\mathrm{P}=32 / 91=0.35
\end{aligned}
$$


then,

$C_{\text {pro }}=(0.65)^{2}+(0.35)^{2}=0.54$

The expected number correct is therefore $0.54(91)=49$.

Then the $\mathrm{X}_{2}$ for performance is 6.37 , and 11.26 for satisfaction.

The classifications, are, in fact, significantly different from chance, using the formula given by Morrison (1969) for computing the proportional chance criterion. Morrison's (1969) proportional chance criterion was used to determine how well the discriminant function correctly identified members of both high and low groups. This criterion showed the probability of correctly classifying into high and low groups rather than the probability of maximizing the percentage correctly classified overall. With this criterion, and the proportion of each group correctly identified, the discriminant function's ability to classify differed significantly from chance at the 0.01 level for performance and at the 0.001 level for satisfaction.

Which of the independent variables are good discriminators? The table gives the discriminant functions $Y^{*}$ and evaluates each coefficient in terms of its contribution to the discrimination between high and low groups. Following Mosteller and Wallace (1963), the relative importance value of each independent variable can be determined. The variables which make the greatest contribution in discriminating between the high performing group and the low performing group are influence over delivery time, authority over collection of credit, and company inside salesmen, and status familiarity and similarity. The importance value of influence over delivery time $(0.176)$ is the contribution it makes toward overall personal selling performance, that is, the difference between the average levels of performance separating high performers and low performers. The positive discriminant coefficient can be interpreted to mean that as a salesman's perceived influence over decisions on delivery time increases, his sales performance increases. Likewise, as salesmen make their suggestions more directly to inside salesmen (0.109), the level of their performance increases. On the other hand, more direct efforts at collection of past due or over-thelimit credit are likely to be associated with less successful sales performance $(-0.176)$. Both status similarity (0.102) and status familiarity (0.128) make positive contributions toward discriminating between the high and low performance groups. Thus, the more the salesman perceives that his customers are like him and the more that he is familiar with their private problems, personal ambitions, and company goals, the greater is his sales performance.

The discriminant coefficients for high and low satisfaction in the table show a different pattern explaining the difference between salesmen with high and low satisfaction than was observed for performance. The important discriminating variables were influence over pricing (0.101) and the type and number of products offered (0.165), authority over collection of credit $(0.200)$ and customers' sales clerks (0.153). As with performance, greater direct efforts at collection of past due or over-the-limit credit are likely to be associated with lower satisfaction.

\section{DISCUSSION}

In this study the outside salesman is viewed as linking his company in an exchange relationship with its customers. The discriminant function for performance indicates that those salesmen who perform the linking function well, adopt a different pattern of interorganizational role-set articulation than do the less successful salesmen. Moreover, the highperformance pattern of interorganizational relations differs from the high satisfaction pattern.

\section{Performance}

The pattern of performance appears to be a function of the salesman's identification with and dependence upon the customers in his role set. Customers are powerfully situated in the role set because of their ability to choose from among competing salesmen, all of whom offer highly undifferentiated commodity products.

The salesman tends to identify with his customers, as reflected in the higher perception of similarity between the higher-performing salesman and his customers and knowing his customers not only as business acquaintances but also as friends. 
The higher frequency of authority over inside salesmen when a customer-related problem arose perhaps indicates that the more successful salesmen were able to protect their familiarity with customers through this authority, thereby nullifying irritating behavior of inside salesmen to customers and thus avoiding endangering their friendships with their customers.

Control over delivery time provides the salesman with power over a function that is crucial, since the distribution of commodity building materials, competing product and price differences are minimal, whereas construction schedules are so critical that delivery time becomes the key differentiating variable among competing suppliers.

The other powerful member of the salesman's interorganizational role-set is his sales supervisor. Thus, the salesman is placed in the position of serving two masters, his customers and his supervisor, each representing different organizations and each having goals which may be conflicting. The salesman's performance seems to increase as a result of asserting some independence from his employer and identifying with his customers, but this maneuver also serves to position the salesman in a marginal role with heightened cross-pressures and tensions (Belasco, 1966; Ditz, 1967; Pruden, 1969b). Therefore, the interorganizational role-set relations which foster higher sales performance may not be conducive to high satisfaction.

\section{Satisfaction}

Conflict appears to be inherent in the salesman's role (Belasco, 1966); thus, the selection of role-set relations by the more satisfied salesman, for example, higher direct influence with regard to customers' sales clerks, suggests the seeking of a position in the role set aimed at minimizing exposure to cross-cutting demands from employer and customers. Among the more satisfied salesmen, the control over the credit function plus the greater ability to rely on the credit manager for collection might avoid problems which would make the salesman's boundaryrole less compatible.

Conformity of role-set relations to the salesman's self-image is also conducive to job satisfaction, and the perceived influence (over product and price functions) and authority (over customers' sales clerks) appear to conform with the self-image that salesmen have of their occupation (Howton \& Rosenberg, 1965).

Predictability of job relationships appears to be closely related to job satisfaction (March and Simon, 1958: 94-95). The high relative discriminating power of the financial aspects of exchange (price and credit) suggests that the desire for predictable or at least stable relations by a highly satisfied salesman over a function is closely controlled by his employer. Discretion over these functions would enable a salesman to reduce conflict during negotiation with his customers.

\section{SUMMARY}

The discriminant function for performance suggests that high performing salesmen tend to identify with their customers who are powerfully situated in their role set. Highperforming salesmen also reported greater influence over a competitively important variable, delivery time.

The discriminant function for satisfaction suggests that highly satisfied salesmen tend to avoid interorganizational conflict. The pattern of role-set relations for collections, price, products, and customers' sales clerks appears to reflect the salesman's ability to avoid or resolve problems with members of his interorganizational role set.

The study constituted an initial step toward the analysis of role-set relationships in an interorganizational context. Its findings achieved moderate success in demonstrating the utility of interorganizational role-set relations as determinants of a salesman's performance and satisfaction. However, since only ninety-one salesmen in one organization participated in the study, the findings cannot be regarded as conclusive, and the suggested explanations for the different patterns or interorganizational role-set relationships can only be tentative. Additional interorganizational role-set relations must be investigated in other settings before it can be concluded that particular patterns of interorganizational relations are determinants of individual performance and satisfaction. 
Henry O. Pruden is an assistant professor of Marketing Administration in the Graduate School of Business at the University of Texas at Austin; Richard M. Reese is an assistant professor of Management in the School of Economics and Management at Oakland University.

\section{REFERENCES}

Belasco, James A.

1966 "The salesman's role revisited." Journal of Marketing, 30: 6-8.

Blalock, Hubert M.

1960 Social Statistics: 218. New York: McGraw-Hill.

Brody, Robert P., and Scott M. Cunningham

1968 "Personality variables and the consumer decision process." Journal of Marketing Research, 5: 50-57.

Cartwright, Dorwin

1965 "Influence, leadership, control." In James G. March (ed.), Handbook of Organizations. Chicago: Rand McNally.

Cotham, James B., III

1968 "Job attitudes and sales performance of major appliance salesmen." Journal of Marketing Research, 5: 370-375.

Ditz, Gerhard

1967 "Status problems of the salesman." Business Topics, 15: 68-80.

Dubin, Robert

1958 The World of Work. Englewood Cliffs: Prentice-Hall.

1968 Human Relations in Administration.

Evan, William Englewood Cliffs: Prentice-Hall.

1965 "The organization set: toward a theory of interorganizational relations." Management Science, 11: 217-230.

Evans, F. B.

1963 "Selling as a dyadic relationship-a new approach." The American Behavioral Scientist, 6: 76-79.

Fisk, George

1967 Marketing Systems. New York: Harper \& Row.

Gadel, M. S.

1964 "Concentration by salesmen on congenial prospects." Journal of Marketing, 28: 64-66.

Green, Paul E., and Donald S. Tull

1966 Research for Marketing Decisions. Englewood Cliffs: Prentice-Hall.
Howton, F. William, and Bernard Rosenberg

1965 "The salesman: ideology and selfimagery in a prototypic occupation." Social Research, 32: 277-298.

Katzell, Raymond A., Richard S. Barrett, and Treadwell C. Parker

1961 "Job satisfaction, job performance, and situational characteristics." Journal of Applied Psychology, 95: 65-72.

Landsberger, Henry A.

1961 "The horizontal dimension in bureaucracy." Administrative Science Quarterly, 7: 299-328.

Litwak, Eugene, and Lydia F. Hylton

1962 "Interorganizational analysis: a hypothesis on coordinating agencies." Administrative Science Quarterly, 6: 395-420.

March, James G., and Herbert A. Simon

1959 Organizations. New York: John Wiley.

McGary, Edmund D.

1951 "The contactual function in marketing." Journal of Business, 24: 96-113.

Miller, E. J., and A. K. Pice

1967 Systems of Organization. London: Tavistock.

Morrison, Donald G.

1969 "On the interpretation of discriminant analysis." Journal of Marketing Research, 6: 158-159.

Mosteller, Frederick, and David L. Wallace

1963 "Inference in an authorship problem." Journal of the American Statistical Association, 58: 275-309.

Pruden, Henry O.

1969a "The outside salesman: interorganizational link." California Management Review, 12: 57-66.

1969b "Interorganizational conflict, linkage and exchange: a study of industrial salesmen." Academy of Management Journal, 12: 339-350.

Pym, D. L. A., and H. D. Auld

1965 "The self-rating as a measure of employee satisfaction." Occupational Psychology, 39: 103-113.

Tausky, Curt

1963 Career Anchorage Points of Middle Managers. Unpublished dissertation, University of Oregon.

Tausky, Curt and Robert Dubin

1965 "Career anchorage: managerial mobility motivations." American Sociological Review, 30: 725-735.

Wittreich, Warren J.

1962 "Misunderstanding the retailer." Harvard Business Review, 40: 147-159. 


\section{APPENDIX}

A. Power: Exclusivity of Accounts and Essentiality of Functions

1. The customer accounts in my territory are under my exclusive jurisdiction. In a sense, they are considered as "belonging to me." No one else from my company would call on these accounts without notifying me beforehand.

How much exclusive

jurisdiction is

there now? (min.) $\frac{1}{1} \frac{1}{3} \frac{1}{4} \frac{1}{6}$ (max.)

2. The amount of influence I have on decisions about the granting of credit to my customers.

How much is

there now?

$$
\text { (min.) } \frac{}{1} \frac{}{2} \frac{1}{3} \frac{}{4} \frac{}{5} \frac{}{6} \text { (max.) }
$$

3. The amount of influence $I$ have on decisions concerning delivery time of products to my customers.

How much is

there now?

$$
\text { (min.) } \frac{}{1} \frac{}{2} \frac{1}{3} \frac{}{4} \frac{}{6} \text { (max.) }
$$

4. The amount of influence I have on decisions about the type and number of products to offer my customers.

How much is

there now?

$$
\text { (min.) } \frac{}{1} \frac{-}{2} \frac{1}{3} \frac{}{5} \frac{}{6}(\max .)
$$

5. The amount of influence I have on a decision concerning the price to charge a customer.

How much is

there now?

$$
\text { (min.) } \frac{}{1} \frac{}{2} \frac{}{3} \frac{}{4} \frac{}{5} \frac{}{6}(\max .)
$$

B. Authority: Lateral and Vertical, Internal and External

1. A salesman finds on occasion that he must select materials especially for a customer. This requires specifying or sorting particular materials from the warehouse inventory. When this situation happens to you:

$\square$ I ask the warehouse directly, and they select what I ask.

I ask the warehouse directly, and they sometimes select what I ask.

I ask my boss and he decides what to ask the warehouse.

I don't ask anyone, I do it myself.

I don't do anything about it.

2. A salesman finds on occasion a customer is irritated with inside salesmen over lack of courtesy, price quotations, unfilled orders, etc. The salesman feels the inside salesmen should be corrected. When this situation happens to you:

I talk to the inside salesmen directly, and they do what I ask.

I talk to the inside salesmen directly, and they sometimes do what I ask.

I talk to my boss, and he decides what to ask the inside salesmen.

I don't say anything about it.

3. When a shipment of material to a customer is below par:

$\square$ The customer's yardmen tell me about it first.

The customer's yardmen tell me about it sometimes.

The customer's yardmen tell their boss, who in turn tells me.

I don't hear about below par material.

4. When a customer is past due or over the limit on his credit:

$\square$ I don't try to sell this customer until he has made payments on his credit.

I don't concern myself with credit.

I ask the credit manager, and he decides what to ask the customer.

$\square$ I ask the customer directly, and he sometimes does what I ask.

$\square$ I ask the customer directly for a payment, and he does what I ask.

5. When I am trying to introduce a new product to a customer:

$\square$ I ask the customer's sales clerks to push the product, and they do what I ask. 
I ask the customer's sales clerks to push the product and they sometimes do what I ask. $\square$ I ask the owner or boss at the customer company and he decides what to ask the sales clerks.

$\square$ I am not concerned about customer's sales clerks.

C. Status: Salesmen-Customer Similarity and Familiarity

1. Which one of the following would best describe the type of customers who purchase from you?

$\square$ They are like me.

$\square$ They are somewhat like me.

$\square$ They are somewhat unlike me.

$\square$ They are different from me.

2. Which of the following best represents the level of familiarity you have with your customers?

$\square$ I know my customers as personal friends as well as business acquaintances. Their private problems and personal ambitions are well known to me. I know most of the company goals for my customers.

$\square$ I know my customers as business acquaintances and as friends. I have some familiarity with their private problems and ambitions. I know many of the company goals of my customers.

$\square$ I know my customers primarily as business acquaintances. Some of their obvious private problems and personal ambitions are known to me. I know some of the company goals of my customers.

$\square$ I know my customers strictly as business acquaintances. Their private problems and personal ambitions are almost unknown to me. I know a few of the company goals of my customers.

\section{Productivity}

A salesman's quantity and quality of performance is measured many ways-sales volume, profits, number of new accounts, and so forth. Comparing yourself to other salesmen in your company doing work similar to yours, how do you rate yourself in terms of quantity and quality of performance?

Overall quantity and quality of performance; check one of the following:

\begin{tabular}{llll}
\hline & & & \\
Near the top- & Above Average- & About Average- & Below Average- \\
Better than 75\% & Better than 50\% & Better than 25\% & Below 25\%
\end{tabular}

\section{E. Satisfaction}

1. Do you feel promotion opportunities are wider in jobs other than yours?

\begin{tabular}{|c|c|c|c|c|c|}
\hline $\begin{array}{c}\text { Definitely } \\
\text { Yes }\end{array}$ & $\begin{array}{c}\text { Probably } \\
\text { Yes }\end{array}$ & $\begin{array}{c}\text { Maybe } \\
\text { Yes }\end{array}$ & $\begin{array}{c}\text { Maybe } \\
\text { No }\end{array}$ & $\begin{array}{c}\text { Probably } \\
\text { No }\end{array}$ & $\begin{array}{c}\text { Definitely } \\
\text { No }\end{array}$ \\
\hline & & & & & \\
\hline
\end{tabular}

2. Do you feel it is as easy to demonstrate ability and initiative in your job as in others?

\begin{tabular}{|c|c|c|c|c|c|}
\hline $\begin{array}{c}\text { Definitely } \\
\text { Yes }\end{array}$ & $\begin{array}{c}\text { Probably } \\
\text { Yes }\end{array}$ & $\begin{array}{c}\text { Maybe } \\
\text { Yes }\end{array}$ & $\begin{array}{c}\text { Maybe } \\
\text { No }\end{array}$ & $\begin{array}{c}\text { Probably } \\
\text { No }\end{array}$ & $\begin{array}{c}\text { Definitely } \\
\text { No }\end{array}$ \\
\hline & & & & & \\
\hline
\end{tabular}

3. Would you advise a friend looking for a new job to take one similar to yours?

\begin{tabular}{|c|c|c|c|c|c|}
\hline $\begin{array}{c}\text { Definitely } \\
\text { Yes }\end{array}$ & $\begin{array}{c}\text { Probably } \\
\text { Yes }\end{array}$ & $\begin{array}{c}\text { Maybe } \\
\text { Yes }\end{array}$ & $\begin{array}{c}\text { Maybe } \\
\text { No }\end{array}$ & $\begin{array}{c}\text { Probably } \\
\text { No }\end{array}$ & $\begin{array}{c}\text { Definitely } \\
\text { No }\end{array}$ \\
\hline & & & & & \\
\hline
\end{tabular}

4. Do you think that there is as much a feeling of security in your job as in others?

\begin{tabular}{|c|c|c|c|c|c|}
\hline $\begin{array}{c}\text { Definitely } \\
\text { Yes }\end{array}$ & $\begin{array}{c}\text { Probably } \\
\text { Yes }\end{array}$ & $\begin{array}{c}\text { Maybe } \\
\text { Yes }\end{array}$ & $\begin{array}{c}\text { Maybe } \\
\text { No }\end{array}$ & $\begin{array}{c}\text { Probably } \\
\text { No }\end{array}$ & $\begin{array}{c}\text { Definitely } \\
\text { No }\end{array}$ \\
\hline & & & & & \\
\hline
\end{tabular}


The LINEAR DISCRIMINANT COEFFICIENTS FOR SALESMEN'S PERFORMANCE AND SATISFACTION* AND THEIR IMPORTANCE

\begin{tabular}{|c|c|c|c|c|c|}
\hline $\begin{array}{l}\text { Independent } \\
\text { variables }\end{array}$ & $\begin{array}{l}\text { Mean } \\
\text { of high } \\
\text { group }\end{array}$ & $\begin{array}{l}\text { Mean } \\
\text { of low } \\
\text { group }\end{array}$ & $\begin{array}{l}\text { Difference } \\
\text { between } \\
\text { mean }\end{array}$ & $\begin{array}{l}\text { Discriminant } \\
\text { coefficient }\end{array}$ & $\begin{array}{c}\text { Importance } \\
\text { value }+\end{array}$ \\
\hline \multicolumn{6}{|l|}{ Power } \\
\hline $\begin{array}{l}\text { Exclusive jurisdiction } \\
\text { over customer accounts }\end{array}$ & 4.88 & 4.44 & 0.44 & 0.041 & 0.018 \\
\hline $\begin{array}{l}\text { Influence over credit } \\
\text { decisions }\end{array}$ & 3.12 & 2.94 & 0.18 & 0.152 & 0.027 \\
\hline $\begin{array}{l}\text { Influence over delivery } \\
\text { time } \\
\text { Influence over type and }\end{array}$ & 4.20 & 3.63 & 0.57 & 0.309 & 0.176 \\
\hline number of products & 4.27 & 4.13 & 0.14 & -0.132 & -0.018 \\
\hline Influence over pricing & 4.20 & 3.75 & 0.45 & 0.050 & 0.023 \\
\hline \multicolumn{6}{|l|}{ Authority (with regard to) } \\
\hline Company warehousemen & 2.08 & 2.25 & -0.17 & -0.161 & 0.027 \\
\hline Company inside salesmen & 1.71 & 2.03 & -0.32 & -0.341 & 0.109 \\
\hline Customer's yardmen & 2.31 & 2.40 & -0.09 & 0.111 & -0.010 \\
\hline Collection of credit & 2.20 & 2.59 & -0.39 & 0.450 & -0.176 \\
\hline Customer's sales clerks & 2.65 & 2.48 & 0.17 & 0.458 & 0.078 \\
\hline \multicolumn{6}{|l|}{ Status } \\
\hline Similarity to customers & 2.07 & 2.28 & -0.21 & -0.488 & 0.102 \\
\hline Familiarity with customers & 2.31 & 2.53 & -0.22 & -0.580 & 0.128 \\
\hline \multicolumn{6}{|l|}{ Power } \\
\hline $\begin{array}{l}\text { Exclusive jurisdiction } \\
\text { over customer accounts }\end{array}$ & 4.86 & 4.55 & 0.31 & -0.014 & -0.004 \\
\hline $\begin{array}{l}\text { Influence over credit } \\
\text { decisions }\end{array}$ & 3.29 & 7.75 & 0.34 & 0.196 & 0.067 \\
\hline Influence over delivery & & & & & \\
\hline time & 4.20 & 3.75 & 0.45 & 0.038 & 0.017 \\
\hline $\begin{array}{l}\text { Influence over type and } \\
\text { number of products }\end{array}$ & 4.53 & 3.83 & 0.70 & 0.236 & 0.165 \\
\hline Influence over pricing & 4.31 & $\begin{array}{l}3.03 \\
3.70\end{array}$ & 0.61 & 0.165 & 0.101 \\
\hline \multicolumn{6}{|l|}{ Authority (with regard to) } \\
\hline Company warehousemen & 2.08 & 2.23 & -0.15 & -0.087 & 0.013 \\
\hline Company inside salesmen & 1.86 & 1.78 & 0.08 & 0.305 & 0.024 \\
\hline Customer's yardmen & 2.31 & 2.38 & -0.07 & 0.003 & 0.000 \\
\hline Collection of credit & 2.14 & 2.60 & -0.46 & -0.435 & 0.200 \\
\hline Customer's sales clerks & 2.48 & 2.74 & -0.26 & -0.588 & 0.153 \\
\hline \multicolumn{6}{|l|}{ Status } \\
\hline Similarity to customers & 2.18 & 2.10 & 0.08 & 0.165 & 0.013 \\
\hline Familiarity with customers & 2.33 & 2.45 & -0.12 & 0.003 & 0.000 \\
\hline
\end{tabular}

* The first figure seen in the table is for performance; the figure below it is for satisfaction.

+ Mosteller and Wallace

Importance value $=$ discriminant coefficient multiplied by the difference between the (mean of the high group and the mean of the low group). 